\title{
The viability of probiotic Lactobacillus acidophilus IFO 13951 and Bifidobacterium longum ATCC 15707 in gummy candies decreased during 4 weeks of storage
}

\author{
1,2,3* Lestari, L.A., ${ }^{1}$ Kusuma, W.I., ${ }^{1}$ Nurhayati, F., ${ }^{1}$ Kusuma, R.J. and ${ }^{2,4}$ Erwanto, Y. \\ ${ }^{1}$ Department of Nutrition and Health, Faculty of Medicine, Public Health and Nursing, Universitas Gadjah \\ Mada, Jalan Farmako, Sekip Utara, Yogyakarta, Indonesia 55281 \\ ${ }^{2}$ Institute for Halal Industry and System, Universitas Gadjah Mada, Yogyakarta, Indonesia 55281 \\ ${ }^{3}$ Center for Health and Human Nutrition, Faculty of Medicine, Public Health and Nursing, Universitas \\ Gadjah Mada, Jalan Farmako, Sekip Utara, Yogyakarta, Indonesia 55281 \\ ${ }^{4}$ Faculty of Animal Science, Universitas Gadjah Mada, Yogyakarta, Indonesia 55281
}

\begin{abstract}
Article history:
Received: 19 February 2020

Received in revised form: 10

March 2020

Accepted: 12 March 2020

Available Online: 3 April

2020
\end{abstract}

Keywords:

Cell viability,

Cell number,

Gummy candies,

Probiotics

DOI:

https://doi.org/10.26656/fr.2017.4(4).078

\begin{abstract}
In addition to fermented milk, incorporation of probiotic bacteria into other food products has been increasing in recent years. Incorporation of probiotic bacteria into gummy candies, a popular chewy gelatin-based candy, is aimed to increase the consumption of probiotics since they have many health benefits. The purpose of this study was to evaluate the viability of probiotic bacteria Lactobacillus acidophilus IFO 13951 and Bifidobacterium longum ATCC 15707 in gummy candies during storage. This research used a true experimental design to evaluate the viability of probiotic bacteria during storage at room temperature $\left(25-30^{\circ} \mathrm{C}\right)$ and cold temperature $\left(4-10^{\circ} \mathrm{C}\right)$. The viable cells of L. acidophilus IFO 13951 were counted with Rogosa agar medium, while $B$. longum ATCC 15707 was counted with Bifidobacterium Selective Medium. The results showed that the reduction of viable cells during 4 weeks of storage ranged between 1.15 to 1.95 $\log$ CFU/g. The highest reduction of probiotic bacteria was found in B. longum ATCC 15707 that has been stored in room temperature. Meanwhile, the viability of $L$. acidophilus IFO 13951 in cold storage temperature was higher than the other probiotic bacteria. Even though there were reductions in cell viability after 4 weeks of storage, the number of probiotic cells ranged between 6.27 to $7.03 \mathrm{log} \mathrm{CFU} / \mathrm{g}$. In conclusion, the number of probiotics in the gummy candy met the criteria of probiotic products based on the cell number. However, further study is needed to extend the self-life of this probiotic gummy candies.
\end{abstract}

\section{Introduction}

Dairy products are the main carriers of probiotic bacteria to humans because milk provides an appropriate environment for probiotic bacteria to support their growth and viability. Nevertheless, with the low milk consumption in ASEAN countries such as Indonesia which is only 14.3 liters per capita, it is particularly challenging to integrate probiotic bacteria into non-dairy probiotic food products, as it must fulfill consumers' standards and expectancy for their health benefits (Stanton et al., 2003).

According to the United Nations World Health Organization for Food and Agriculture, probiotics bacteria are defined as "live microorganisms which when administered in adequate amounts confer a health benefit on the host" (FAO/WHO, 2002). Hence, the probiotic bacteria have to be alive, while heat-killed or tyndalized probiotics do not meet with these criteria. Monitoring the viability of probiotic bacteria is essential to make sure that the probiotic cells are still alive.

Among the probiotics, Lactobacillus spp. and Bifidobacterium spp. are well known because they have many beneficial characteristics such as pathogenic microbes control (Garcia et al., 2016). We used two strains of probiotic bacteria namely Lactobacillus acidophilus IFO 13951 and Bifidobacterium longum ATCC 15707. L. acidophilus is gram-positive rodshaped microbes with rounded ends. Usually, the width is $0.6 \pm 0.9 \mu \mathrm{m}$ and the length is $1.5 \pm 6.0 \mu \mathrm{m}$. These are 
non-flagellated, non-motile and non-spore forming, and salt-intolerant. L. acidophilus is widely used as probiotic bacteria and has been studied intensively for its health benefits (Gomes and Malcata, 1999). B. longum is anaerobic, non-sporulating Gram-positive rod-shaped microbes representing ubiquitous inhabitants of the human gastrointestinal tract and vagina (Esaiassen et al., 2017). B. longum may be considered the most common species of Bifidobacterium, being found both in infant and adult feces (Bivati et al., 1984). The health benefits of B. longum are action toward intestinal pathogens, improved lactose utilization, anticarcinogenic action and control of serum cholesterol levels (Ibraheem et al., 2015).

It is important to assess the viability of strain in the carrier food at the time of consumption. Survival of probiotic strain depends on the $\mathrm{pH}$, processing and storage temperature, and presence of microbial inhibitors such as $\mathrm{NaCl}$ and hydrogen peroxide in the food matrix (Kurmann and Rasic, 1991). In addition, it is important that probiotic products at the moment of consumption contain a sufficient number of active cells, i.e. at least $10^{6} \mathrm{CFU} / \mathrm{g}$ (Rasic and Kurmann, 1983). A probiotic strain must, therefore, have good longevity, both in the product and in the gastrointestinal tract after digestion. During the gummy candies processing, there are several heating processes that might kill the probiotic bacteria. To monitor the survivability of probiotic bacteria in gummy candies, we evaluated the viability of probiotic cells after processing of gummy candies and during storage at room and cold temperature.

\section{Material and methods}

\subsection{Gummy candies formula and preparation}

$L$ acidophilus IFO 13951 and B. longum ATCC 15707 were obtained from the Food and Nutrition Culture Collection (FNCC), Center for Food and Nutrition Studies, Universitas Gadjah Mada, Indonesia. The cultures were kept at $-20^{\circ} \mathrm{C}$ in $10 \%$ skim milk (w/v) and $10 \%$ glycerol $(\mathrm{w} / \mathrm{v})$. For the preparation of gummy candies, frozen cultures were streaked onto Rogosa agar medium (Oxoid) for L. acidophilus IFO 13951 and Bifidobacterium Selective Media (BSM, Himedia) for $B$. longum ATCC 15707, followed by incubation at $37^{\circ} \mathrm{C}$ for 24-48 hrs. Then, one colony from each plate was transferred into $10 \mathrm{~mL}$ of MRS broth (Oxoid) and incubated overnight. The cell suspension was centrifuged at $3000 \mathrm{rpm}$ for $10 \mathrm{~min}$, and the pellet was washed with phosphate buffered saline twice. The number of $L$. acidophilus IFO 13951 and B. longum ATCC 15707 in the cell suspensions were $1.12 \times 10^{9}$ and $3.40 \times 10^{9} \mathrm{CFU} /$ $\mathrm{mL}$, respectively.
The formula of gummy candies consisted of fructooligosaccharide (FOS, Orafti P95), glucose syrup, water, bovine gelatine $40 \%$ (Gelita), citric acid, and food additives. First, gelatin powder was soaked for $30 \mathrm{mins}$ in water, then gelatin was melted at $60^{\circ} \mathrm{C}$ for 15 mins by heating. In the mixture under heating, FOS after glucose syrup was added and dissolved. Citric acid, food additive (fruit flavoring, food coloring, and sucralose), and probiotics were incorporated into the gummy candy mixture at the end of the process (temperature $40^{\circ} \mathrm{C}$ ), then the mixture was poured into casts (Kusuma et al., 2018; Nurhayati et al., 2019).

\subsection{The evaluation of cell viability}

The viable cells of $L$. acidophilus IFO 13951 and $B$. longum ATCC 15707 were counted using different agar mediums. Rogosa agar medium was used to count the viable cells of L. acidophilus IFO 13951, while Bifidobacterium Selective Count Agar Base (BSC, Himedia) supplemented with Bifidobacterium Selective Supplement A (FD250, Himedia) and Bifidobacterium Selective Supplement B (FD251, Himedia) were used to count the viable cells of B. longum ATCC 15707.

As much as $90 \mathrm{~mL}$ of phosphate buffered saline (PBS) homogenized with $10 \mathrm{~g}$ of sample. Serial dilution of $10^{-5}$ to $10^{-7}$ with PBS was used for cell counting. As much as $1 \mathrm{~mL}$ of diluted sample was put into a sterile Petri dish, poured with Rogosa agar medium or BSC agar, and then mixed thoroughly by shaking the Petri dish. The Petri dish/plates were incubated at $37^{\circ} \mathrm{C}$ for 48 hours, under microaerobic condition for $L$. acidophilus or anaerobic for B. longum. The number of bacterial colonies per gram of samples was measured and expressed as a decimal log of colony forming units (log $\mathrm{CFU} / \mathrm{g})$.

\subsection{Statistical analysis}

The data were presented in mean \pm standard deviation and analyzed with SPSS 16.0 statistical software (SPSS, Inc., Chicago, IL, USA). One-way ANOVA test was used to compare the number of viable cells during storage. The two-way ANOVA was performed to evaluate which variable that affects the cell viability and the interaction between variables/factors. The value $p<0.05$ was considered statistically significant.

\section{Results and discussion}

There are several factors that must be addressed in evaluating the effectiveness of the incorporation of the probiotic strains into food products, namely safety, the compatibility of microorganism in the product, and the 
viability of the cells during processing, packaging, and storage (Kechagia et al., 2013). Most probiotic products contain Lactobacillus plantarum, Lactobacillus acidophilus, Lactobacillus fermentum, Lactobacillus rhamnosus, Bifidobacterium bifidum, or Bifidobacterium longum. However, in commercial probiotic gummy candies there are only spore forming bacteria, namely Bacillus coagulans and Bacillus subtilis since they form heat resistant spores that could survive during processing, packaging, and storage (Posnick, 2018). Although Bacillus coagulans and Bacillus subtilis are already approved by Food and Drug Administration (FDA) as Generally Recognized as Safe (GRAS), however since they are in the form of spores instead of vegetative cells hence there are contradictory points of view between scientists regarding these spores forming probiotics.

The viable probiotic cells count in gummy candies during storage is given in Figure 1. After processing and in day 0 of storage, the number of viable cells in all gummy candies were higher than $8.0 \log _{10} \mathrm{CFU} / \mathrm{g}$. Hence, the number of probiotic cells in the food product has met the recommended number of probiotic cells which is minimal $6.0 \log _{10} \mathrm{CFU} / \mathrm{g}$ or $\mathrm{mL}$ of food product (Boylston et al., 2004). However, the food industry suggested daily intake of at least $10^{8}-10^{9}$ viable cells in order to provide a probiotic effect since we have to consider survival rates of probiotic cells in the gastrointestinal tract. Health benefits of probiotics include they are anti-pathogenic bacteria, lower serum cholesterol level, increase nutrient absorption, and decrease the use of antibiotics (Guo et al., 2010).

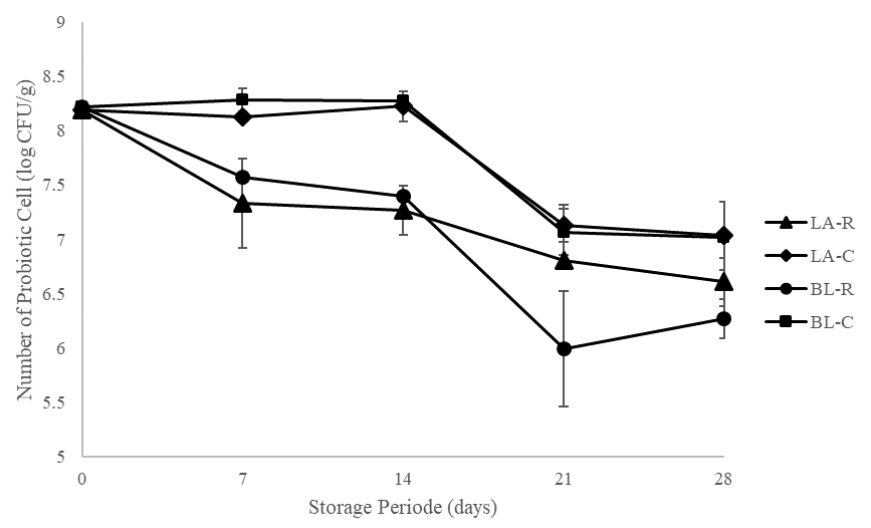

Figure 1. Viable probiotic cells count in gummy candies during storage. LA-R: L. acidophilus IFO 1395, stored in room temperature, LA-C: L. acidophilus IFO 1395, stored in cold temperature, BL-R: B. longum ATCC 15707, stored in room temperature, and BL-C: B. longum ATCC 15707, stored in cold temperature.

Storage at cold temperature resulted in the higher survival rate compared to at the room temperature. $L$. acidophilus IFO 13951 had good viability compared to B. longum ATCC 15707. The results showed that the reduction of viable cells during 4 weeks of storage ranged between 1.15 to $1.95 \log \mathrm{CFU} / \mathrm{g}$ (Figure 2). The highest reduction of probiotic bacteria was found in $B$. longum ATCC 15707 that has been stored in room temperature. Meanwhile, the viability of $L$. acidophilus IFO 13951 in cold storage temperature was higher than other probiotic bacteria. The number of $L$. acidophilus IFO 13951 and B. longum ATCC 15707 stored at room temperature significantly decreased after 7 days of storage. However, when they were stored at cold temperature, the number of L. acidophilus IFO 13951 was significantly decreased after 21 days of storage, while the number of $B$. longum ATCC 15707 did not change (Table 1). Even though there were reductions of cell viability after 4 weeks of storage, the number of probiotic cells ranged between 6.27 to $7.03 \log \mathrm{CFU} / \mathrm{g}$, hence the probiotic gummy candy met the criteria of a probiotic product based on the cell number.

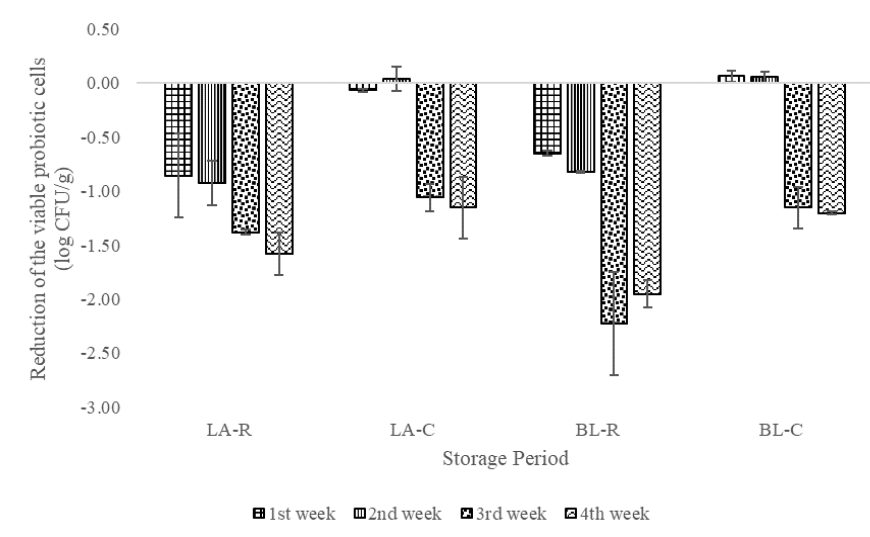

Figure 2. Reduction of the viable probiotic cells during storage. LA-R: L. acidophilus IFO 1395, stored in room temperature, LA-C: L. acidophilus IFO 1395, stored in cold temperature, BL-R: B. longum ATCC 15707, stored in room temperature, and BL-C: Bifidobacterium longum ATCC 15707, stored in cold temperature.

The reduction of probiotic cells might be due to the use of free cells instead of immobilized cells. Immobilized cells have many advantages such as protecting cells against damage and contamination during processing. On the other hand, immobilization of probiotic cells would increase its cost (Burgain et al., 2011).

The viability of B. longum ATCC 15707 in gummy candies stored in room temperature was lower than $L$. acidophilus IFO 13951 at the same storage condition. This result might be due to the requirement of specific amino acids and small peptides to stimulate the growth of Bifidobacteria. Bifidobacteria are also very sensitive to environmental parameters and require expensive media for propagation and the addition of growthpromoting factors, due to their stringent growth requirements (Ibrahim and Bezkorovainy, 1994). Gummy candies contain gelatin that is rich in amino 
Table 1 . The number of probiotic cells, expressed as $\log \mathrm{CFU} / \mathrm{g}$, in gummy candies during storage at room and cold temperature

\begin{tabular}{ccccc}
\hline \multirow{2}{*}{$\begin{array}{c}\text { Storage Time } \\
\text { (days) }\end{array}$} & \multicolumn{2}{c}{ Lactobacillus acidophilus IFO 13951 } & \multicolumn{2}{c}{ Bifidobacterium longum ATCC 15707 } \\
\cline { 2 - 5 } & Room Temperature $\left(28^{\circ} \mathrm{C}\right)$ & Cold Temperature $\left(4^{\circ} \mathrm{C}\right)$ & Room Temperature $\left(28^{\circ} \mathrm{C}\right)$ & Cold Temperature $\left(4^{\circ} \mathrm{C}\right)$ \\
\hline 0 & $8.19 \pm 0.02^{\mathrm{a}}$ & $8.19 \pm 0.02^{\mathrm{a}}$ & $8.22 \pm 0.06^{\mathrm{a}}$ & $8.22 \pm 0.06$ \\
7 & $7.33 \pm 0.41^{\mathrm{b}}$ & $8.12 \pm 0.01^{\mathrm{a}}$ & $7.57 \pm 0.04^{\mathrm{b}}$ & $8.29 \pm 0.04$ \\
14 & $7.26 \pm 0.23^{\mathrm{b}}$ & $8.22 \pm 0.14^{\mathrm{a}}$ & $7.39 \pm 0.05^{\mathrm{b}}$ & $8.28 \pm 0.01$ \\
21 & $6.81 \pm 0.05^{\mathrm{b}, \mathrm{c}}$ & $7.13 \pm 0.15^{\mathrm{b}}$ & $5.99 \pm 0.53^{\mathrm{c}}$ & $7.07 \pm 0.25$ \\
28 & $6.61 \pm 0.22^{\mathrm{c}}$ & $7.03 \pm 0.31^{\mathrm{b}}$ & $6.27 \pm 0.18^{\mathrm{c}}$ & $7.02 \pm 0.04$ \\
P value & 0.007 & 0.002 & 0.001 & 0.12 \\
\hline
\end{tabular}

acids which are varied among different sources, i.e. types of animal (pork, bovine, fish, etc.) and also different parts of animal bodies (skins or bones) (GMIA, 2012; Arsyanti et al., 2018). However, due to low water activity, Bifidobacteria could not utilize these amino acids.

Based on the two-way ANOVA test, it was found that storage time and temperature significantly affect the viability of $L$. acidophilus IFO 13951 and B. longum ATCC 15707 in gummy candies since both factors have $\mathrm{p}$-value $<0.001$. However, there was no significant interaction effect of storage time and temperature ( $p$ value $=0.793$ ).

\section{Conclusion}

L. acidophilus IFO 13951 and B. longum ATCC 15707 could survive after processing of gummy candies. Although the viable cells of L. acidophilus IFO 13951 and B. longum ATCC 15707 decreased, the number of these probiotic bacteria in gummy candies ranged between 6.27 to $7.03 \log \mathrm{CFU} / \mathrm{g}$ so that they had met the criteria of probiotic products based on the cell number.

\section{Acknowledgements}

The authors extend their thanks to the Ministry of Research and Higher education via research scheme Penelitian Unggulan Perguruan Tinggi 2017 awarded to Dr. Lily Arsanti Lestari with contract number: 2379/ UN1.P.III/DIT-LIT/LT/2017. Thanks to the native speaker and professional editor in Klinik Bahasa (Language Clinic) Consultation, Office of Research and Publication, Faculty of Medicine, Public Health, and Nursing, Universitas Gadjah Mada for reviewing this article.

\section{Conflict of interest}

The authors declare no conflict of interest.

\section{References}

Arsyanti, L., Erwanto, Y., Rohman, A. and Pranoto, Y. (2018). Chemical composition and characterization of skin gelatin from buffalo (Bubalus bubalis). International Food Research Journal, 5(3),10951099.

Bivati, B., Castagnoli, P. and Trovatelli, L.D. (1984). Species of the genus Bifidobacterium in the feaces of human adults. Microbiology, 9(1), 39-45.

Boylston, T.D., Vinderola, C.G., Ghoddusi, H.B. and Reinheimer, J.A. (2004). Incorporation of bifidobacteria into cheeses: challenges and rewards. International Dairy Journal, 14(5), 375-387. https:// doi.org/10.1016/j.idairyj.2003.08.008

Burgain, J., Gaiani, C., Linder, M. and Scher, J. (2011). Encapsulation of probiotic living cells: from laboratory scale to industrial applications. Journal of Food Engineering, 104(4), 467-483. https:// doi.org/10.1016/j.jfoodeng.2010.12.031

Esaiassen, E., Hjerde, E., Cavanagh, J.P., Simonsen, G.S. and Klingenberg, C. (2017). Bifidobacterium Bacteremia: Clinical Characteristics and a Genomic Approach to Assess Pathogenicity. Journal of Clinical Microbiology, 55(7), 2234-2248. https:// doi.org/10.1128/JCM.00150-17

FAO/WHO. (2002). Working Group on Drafting Guidelines for the Evaluation of Probiotics in Food. Guidelines for the evaluation of probiotics in food: report of a Joint FAO/WHO Working Group on Drafting Guidelines for the Evaluation of Probiotics in Food. London Ontario, Canada: FAO and WHO.

Garcia, E.F., Luciano, W.A., Xavier, D.E., Da Costa, W.C., De Sousa Oliveira, K., Franco, O.L. and Saarela, M. (2016). Identification of lactic acid bacteria in fruit pulp processing byproducts and potential probiotic properties of selected Lactobacillus strains. Frontiers Microbiology, 7 (1371), 1-11. https://doi.org/10.3389/ fmicb.2016.01371

GMIA (Gelatin Manufacturers Institute of America). (2012). Gelatin Handbook. Retrieved on 16 August 2018 from http://www.gelatin-gmia.com/images/ 
GMIA_Gelatin_Manual_2012.pdf

Gomes, A.M.P. and Malcata, X.F. (1999). Bifidobacterium ssp. and Lactobacillus acidophilus: Biological, Biochemical, Technological and Therapeutical Properties Relevant for Use as Probiotics. Trends Food Science and Technology, 10 (4-5), 139-157. https://doi.org/10.1016/S0924-2244 (99)00033-3

Guo, X.H., Kim, J.M., Namb, H.M., Park, S.Y. and Kim, J.M. (2010). Screening lactic acid bacteria from swine origins for multistrain probiotics based on in vitro functional properties. Anaerobe, 16(4), 321326. https://doi.org/10.1016/j.anaerobe.2010.03.006

Ibraheem, S.E., Kabeir, B.M. and Mohammed, L.H. (2015). Survival of Bifidobacterium longum BB536 and Physicochemical Changes during Refrigeration Storage of Fermented Roasted Peanuts Milk Partially Substituted with Millet Thin Porridge. International Journal of Current Microbiology and Applied Science, 4(9), 380-389.

Ibrahim, S.A. and Bezkorovainy, A. (1994). Growthpromoting factors for Bifidobacterium longum. Journal of Food Science, 59(1), 189-191. https:// doi.org/10.1111/j.1365-2621.1994.tb06929.x

Kechagia, M., Basoulis, D., Konstantopoulou, S., Dimitriadi, D., Gyftopoulou, K., Skarmoutsou, N. and Fakiri, E.M. (2013). Health benefits of probiotics: a review. ISRN Nutrition, 2013, 481651. https://doi.org/10.5402/2013/481651

Kurmann, J.A. and Rasic, J.L. (1991). The Health Potential of Products Containing Bifidobacteria. In Robinson, R.K. (Ed.) Therapeutic Properties of Fermented Milks., p. 117-157. London: Elsevier Applied Science Publishers.

Kusuma, W.I., Lestari, L.A. and Kusuma, R.J. (2018). Viabilitas Lactobacillus acidophilus IFO 13951 pada Sediaan Berbentuk Permen Jelly Selama Penyimpanan. Yogyakarta, Indonesia: Universitas Gadjah Mada, BSc. Thesis. [In Bahasa Indonesia]

Nurhayati, F., Lestari, L.A. and Kusuma, R.J. (2019). Viabilitas Bifidobacterium longum ATCC 15707 pada Sediaan Berbentuk Permen Jelly Selama Penyimpanan. Yogyakarta, Indonesia: Universitas Gadjah Mada, BSc. Thesis. [In Bahasa Indonesia]

Posnick, Y. (2018). The 10 Best Probiotics Gummies. Retrieved on 16 August 2018 from http:// www.sheknows.com/best-reviews/probioticsgummies

Rasic, J.L. and Kurmann, J.A. (1983). Bifidobacteria and Their Role. Switzerland: Springer Basel AG. https:// doi.org/10.1007/978-3-0348-5448-1
Stanton, C., Desmond, C., Coakley, M., Collins, J.K., Fitzgerald, G. and Ross, R.P. (2003). Challenges facing development of probiotic-containing functional foods. In Farnworth, E. (Ed). Handbook of fermented functional foods., p. 27-58. Boca Raton, USA: CRC Press. https:// doi.org/10.1201/9780203009727.ch2 